\title{
Beech (Fagus sylvatica L.) - Technological properties, adhesion behaviour and colour stability with and without coatings of the red heartwood
}

\author{
Evelyn PöHLER*, Raoul KLINGNER, Tina KÜNNIGER
}

EMPA, Swiss Federal Laboratories for Materials Testing and Research, Wood Laboratory, Überlandstrasse 129, 8600 Dübendorf, Switzerland

(Received 17 January 2005; accepted 7 October 2005)

\begin{abstract}
European beech (Fagus sylvatica L.) is a popular and major tree species in Europe. The economic value of its timber is greatly decreased by the red heart phenomenon. The cause of red heart formation is well understood. However, scientific investigations about the technological and mechanical behaviour of red heartwood are scarce. Our study aims to provide a sound scientific basis for the characterization of technological properties, adhesion- as well as colour-behaviour of red-hearted beech. The mechanical and technological properties of redhearted beech give no evidence of different behaviour in comparison with the normal beech wood. The adhesion behaviour shows equal results. In terms of colour stability, the difference between freshly processed normal and red beech wood diminishes after certain time of exposure.
\end{abstract}

red heart / adhesion behaviour / colour stability / mechanical technological property / Fagus sylvatica

\begin{abstract}
Résumé - Le bois de hêtre (Fagus sylvatica L.) - Propriétés technologiques, comportement au collage et stabilité de la teinte du bois de cœur rouge. Le hêtre (Fagus sylvatica L.) est une espèce d'arbre populaire important en Europe. La présence du cœur rouge provoque une réduction notable de la valeur économique des grumes qui en sont atteintes. Les causes de l'apparition du cour rouge sont bien connues mais les études scientifiques sur le comportement technologique et mécanique du hêtre à cœur rouge sont cependant rares. La présente étude a pour but d'établir des bases solides pour la caractérisation des propriétés technologiques du hêtre à cœur rouge que sont le comportement au collage et la stabilité de teinte. Il n'existe aucun indice selon lequel les propriétés technologiques et mécaniques du hêtre à cœur rouge diffèrent de celle du hêtre normal. Pour ce qui est du comportement au collage, les résultats sont identiques alors que pour la stabilité de la teinte la différence à l'état frais de sciage entre le hêtre normal et le hêtre à cœur rouge diminue après un certain temps d'exposition.
\end{abstract}

cœur rouge / comportement au collage / stabilité de teinte / propriété technologique et mécanique / Fagus sylvatica

\section{INTRODUCTION}

Beech (Fagus sylvatica L.) is next to oak the most important hardwood tree in Central and Eastern Europe with an area of about 12 millions hectare [31]. Beech forests account for approximately $19 \%$ of the forest area of Switzerland [17],15\% of Germany [13] and 9.4\% of the total area in France [14]. The economic importance of beech increased in the last years by the continuous demand for bright and evenly coloured grades and the export of beech logs and sawn timber to Asia.

The disadvantage of beech lays in its relatively low proportion of stem wood, which is only approximately $50 \%$ compared to $90 \%$ in the case of spruce. Moreover about $75 \%$ of the bole is of rather low quality (grade $\mathrm{C}$ timber), mainly because of the high proportion of red heart amongst older trees [22]. The red heartwood formation in the living tree as well as discolouration during storage or kiln-drying cause an important loss of financial value of beech [12]. The colour of wood is an important factor for end user to consider and the price of wood is often dependent on its colour parameter [23]. Causes and conse- quences of discolouration are reviewed by Koch et al. [26, 27]. In the living tree the colour change is initiated predominantly through wounds, dying branches and roots. When oxygen penetrates the tissues, accessory compounds and tyloses are synthesised through physiological and biochemical reactions.

This study aims to investigate whether such a financial devaluation is justified in terms of the decline of technological properties of red-hearted beech wood. Although the formation of red heart in the living tree is well described [16, 28], scientific literature about the relevant mechanical and technological properties of red-hearted beech is scarce $[30,36]$. A classification for the adhesion behaviour of red-hearted beech cannot be found in the literature. Concerning the variations of beech wood colour parameters investigations were carried out by Shengquan et al. [34] to study the influence of site and tree effect on colour.

Considering the affluent supply of red-hearted beech wood also in the future it seems to be of interest to look for alternatives and higher revenue in its utilization. The use of red-hearted beech in products of large volume such as gluelam and in the

* Corresponding author: evelyn.poehler@empa.ch 
Table I. Surface treatments studied.

\begin{tabular}{|c|c|c|c|c|c|c|c|}
\hline & \multirow{2}{*}{ Substrate } & \multirow{2}{*}{ Sample series } & \multirow{2}{*}{$\begin{array}{l}\text { Specimen } \\
\text { group }\end{array}$} & \multicolumn{3}{|c|}{ Basic composition of the Finish } & \multirow{2}{*}{ Nomination } \\
\hline & & & & Binder (resin) & Solvent & Colour stabilizers & \\
\hline \multirow{7}{*}{$\begin{array}{l}\text { First } \\
\text { series }\end{array}$} & \multirow{7}{*}{ Wood veneer } & \multirow{7}{*}{$\begin{array}{l}\text { Established } \\
\text { finishes }\end{array}$} & 1.0 & Untreated surface & & - & \\
\hline & & & 1.1 & Oil & & - & \\
\hline & & & 1.2 & Wax & & - & \\
\hline & & & 1.3 & PUR/Acrylate-Copolymer & Water & - & \\
\hline & & & 1.4 & PUR/Acrylate/PE & Solvent & - & \\
\hline & & & 1.5 & Nitrocellulose/Alkyd resin & Solvent & - & \\
\hline & & & 1.6 & Acrylate & Water & - & \\
\hline \multirow{6}{*}{$\begin{array}{l}\text { Second } \\
\text { series }\end{array}$} & \multirow{6}{*}{ Solid wood } & \multirow{6}{*}{$\begin{array}{l}\text { Newly developed } \\
\text { finishes }\end{array}$} & 2.0 & Untreated surface & & & \\
\hline & & & 2.1 & PUR/Acrylate/PE & Solvent & HALS + UVA & $A+B$ \\
\hline & & & 2.2 & PUR/Acrylate/PE & Solvent & HALS + UVA & $\mathrm{A}+\mathrm{C}$ \\
\hline & & & 2.3 & Acrylate & Water & Nano pigment & $\mathrm{D}$ \\
\hline & & & 2.4 & Synthetic resin & Solvent & None & $\mathrm{E}$ \\
\hline & & & 2.5 & Acrylate & Water & HALS + UVA & $\mathrm{F}+\mathrm{G}$ \\
\hline
\end{tabular}

furniture and flooring industries would be desirable. The goal of this study is therefore to provide scientific data on physical and mechanical properties of red heartwood as a basis for broader utilisation possibilities and added value in revenue.

\section{MATERIALS AND METHODS}

All investigations were carried out with samples of normal and redhearted beech wood. Five beech logs (Fagus sylvatica L.) were selected for the determination of the physical, mechanical and technological properties, colour stability and investigations of the gluing characteristics. After sawing and kiln-drying, the wood was stored in standard climate $\left(20^{\circ} \mathrm{C} / 65 \%\right.$ r.H. $)$. Each log provided red-hearted and normal samples. Here the results of all samples are grouped together. The data representing are more detailed log by log investigation are shown elsewhere [32]. For the examination of the stability of colour, additional samples of rotary-cut veneer were used, that were steamed for $60 \mathrm{~h}$, dried and conditioned before investigation.

\subsection{Physical, mechanical and technological properties}

As a basis for further investigations the following mechanical properties of the sample material were measured: bending modulus of elasticity and bending strength (DIN 52186 [7]), density (DIN 52182 [8]) and moisture content (DIN 52183 [9]).

In order to evaluate the effect of the distribution of the earlywood and latewood within the samples for the elastomechanical investigations, the number of the annual growth rings was determined on the cross section of the bending test samples $(20 \mathrm{~mm})$.

The shrinking and swelling behaviour was examined according to DIN 52184 [10]. In each case the density, the swelling ratios in radial and tangential direction as well as the swelling anisotropy were determined. The differential swelling is the proportional swelling size in percent change of wood moisture. The swelling anisotropy is the relationship of the tangential to the radial differential swelling of the wood.

The wood equilibrium moisture content was determined after conditioning at $35 \%, 65 \%$ and $85 \%$ relative humidity at a temperature of $20{ }^{\circ} \mathrm{C}$.

Brinell-hardness was measured according to the method described by Stübi and Niemz [35] by the penetration of a steel ball into the wood surface. The investigation was carried out according to DIN EN 1534 [11] with a test load of $1000 \mathrm{~N}$. The ball was loaded and reloaded for
$20 \mathrm{sec}$ and the time of retention of the maximal load was $30 \mathrm{sec}$. The samples were cut in dimensions of $40 \times 40 \mathrm{~mm}^{2}$ at a maximally attainable length but not less than $500 \mathrm{~mm}$. For each individual tree 2 sample bars with red heart and 2 sample bars of normal wood were investigated. For each sample 30 measurements were made in radial and tangential direction with $2 \mathrm{~cm}$ distance from each other. The number of measurements per tree and direction of cutting was 60 .

\subsection{Colour behaviour}

Investigations on the behaviour of differently coated beech surfaces following xenon-arc irradiation were performed in two test series.

The first sample series included well-established surface treatments used in the furniture industry (see Tab. I, samples 1.1-1.6). Five different finishing systems were used. Their behaviour was investigated in parallel on normal and red-hearted beech respectively. In the first series the coatings were applied on veneer. The veneer was steamed, dried and sanded with abrasive paper of grit size 120 . The sheets were cut into samples of $40 \times 100 \mathrm{~mm}^{2}$ and conditioned in standard climate $\left(20{ }^{\circ} \mathrm{C} / 65 \%\right.$ r.H.) until coating and treatment.

The second sample series involved newly developed surface treatment products containing components of the following special UVabsorbing or radical trapping additives:

- Product A with sterically hindered amines (HALS);

- Product B with UV absorber (hydroxyphenyl-benzotrialzole);

- Product $\mathrm{C}$ with UV absorber (triazine derivate in methoxypropylacetate);

- Product $\mathrm{D}$ with micronized transparent rutile grades of $\mathrm{TiO}_{2}$ coated with $\mathrm{Al}_{2} \mathrm{O}_{3}$;

- Product E, one component lacquer of a synthetic resin;

- Product F with UV absorber (benzotrialzole);

- Product $\mathrm{G}$ with sterically hindered amines (HALS).

Five different coating systems were used and compared (see Tab. I, samples 2.1-2.5).

The second set of coatings was applied on solid wood. The boards were dried and sanded just like in the first group, cut into pieces of $40 \times 100$ $\mathrm{mm}^{2}$ with a thickness of $5 \mathrm{~mm}$. The surface treatments used for the investigation of the behaviour of coated surfaces are listed in Table I.

The systems were mixed and manually applied by brush according to the manufacturer's specifications. The thickness of the coatings was investigated following DIN ISO 2808 [6]. 
Table II. Used treatments according to EN 302-1 [1]

\begin{tabular}{cc}
\hline A1-Treatment, dry testing & A4-Treatment, wet testing \\
\hline Test immediately after obligatory & 6 h soaking in boiling water \\
7 days in standard climate (20/65) & $\begin{array}{c}2 \mathrm{~h} \text { soaking in water at }(20 \pm 5)^{\circ} \mathrm{C} \\
\text { Samples tested in the wet state }\end{array}$ \\
\hline
\end{tabular}

Accelerated aging of the sample surfaces was performed with xenon-arc radiation in an Atlas Ci35A Xenon weatherometer according to DIN 53387 [3]. The spectral fraction of the xenon source is adapted to the sunlight's spectrum. Filters for indoor-light (borsilicate/ sodalime filter system) are used to simulate light filtration through glass panes. The samples were exposed continuously for $480 \mathrm{~h}$ in cycles of $48 \mathrm{~h}$ at a temperature of $40{ }^{\circ} \mathrm{C}$ and a relative humidity of $40 \%$. After every cycle the samples were photographed, visually examined and their colour change was measured with a Microflash $200 \mathrm{~d} \mathrm{spec-}$ trophotometer.

The investigation of the colour effect is standardized [5]. The measurement of colour was performed according to DIN 6174 [4]. The CIELAB colour space is composed of a lightness value $\mathrm{L}^{*}$, a greenness-redness value $\mathrm{a}^{*}$ on the abscissa and blueness-yellowness value $\mathrm{b}^{*}$ on the ordinate. The $\mathrm{L}^{*}$-, $\mathrm{a}^{*}$ - and $\mathrm{b}^{*}$-values of an investigated sample together with a corresponding reference value determine the objective lightness difference value $\Delta \mathrm{L}^{*}$, the difference in red and yellow chromatic coordinates $\Delta \mathrm{a}^{*}$ and $\Delta \mathrm{b}^{*}$, and consequently the colour difference $\Delta \mathrm{E}^{*}$. Another form of colour differentiation is the chroma $\mathrm{C}^{*}$.

$$
\begin{gathered}
\Delta L^{*}=L_{\text {test }}^{*}-L_{\text {reference }}^{*} \\
\Delta E^{*}=\left[\left(\Delta L^{*}\right)^{2}+\left(\Delta a^{*}\right)^{2}+\left(\Delta b^{*}\right)^{2}\right]^{1 / 2} \\
C^{*}=\sqrt{\left(a^{* 2}+b^{* 2}\right)}
\end{gathered}
$$

In the CIE-measuring system the lightness difference value $\Delta \mathrm{L}^{*}$ between an unexposed reference sample $\mathrm{L}^{*}$ reference and the xenon exposed $\mathrm{L}^{*}{ }_{\text {test }}$ is defined as the psychometric lightness difference. The total difference $\Delta \mathrm{E}^{*}$ of two colours is the geometric distance of their position the CIELAB colour space.

\subsection{Adhesion properties}

Longitudinal shear strength of adhesive bonds of red-hearted beech wood in comparison with normal beech wood was determined in accordance with EN 302-1 [1]. Two types of adhesives were used: A 1-part polyurethane adhesive (1 P PUR) and a Melamine-Urea-For- maldehyde (MUF) polycondensation resin. Both adhesives are certified for application in load bearing timber structures.

The instructions for applications recommended by the adhesive manufacturers were respected. Only test pieces with close contact joints of $0.1 \mathrm{~mm}$ glueline thickness were produced and tested. Two systems of treatment (A1, A4) were applied prior to tensile shear testing in order to investigate the quality of adhesion (Tab. II).

A batch of 10 specimens was tested for each combination of the treatment and type of adhesive. For every tested specimen a visual inspection was carried out to estimate and record the percentage of wood failure to the nearest $10 \%$. To characterize the quality of gluing, the gluelines and the adjacent wood structure were analysed by light microscope.

\section{RESULTS}

\subsection{Physical, mechanical and technological properties}

The results of the physical, mechanical and technological investigations are presented in Table III.

The comparison of the differences within the individual trees investigated was partly more significant, but generally confirms the results across all investigated samples. The density range of the examined beech wood of all sample logs is between $650-760 \mathrm{~kg} / \mathrm{m}^{3}$. The density of the red-hearted assortment is in average higher $(+2.74 \%)$. According to the slightly higher density of the red-hearted samples also the moisture content of the samples behaves similarly $(+3.26 \%)$. Apart from the differences in density and wood moisture content the average year ring width of the red-hearted samples is slightly higher.

In comparison of the modulus of elasticity and the bending strength of normal beech and beech with red heart, the latter samples achieved somewhat significantly higher values $(+6.1 \%$ for the modulus of elasticity and $+7.09 \%$ for the bending strength).

The swelling behaviour of the beech with red heart is slightly increased. The hygroscopic behaviour of the red-hearted beech wood is however more homogeneous. This shows up in the lower swelling anisotropy (-9.05\%). While the differential swelling ratios are almost the same for normal and red-hearted wood in tangential direction, the differences in radial direction $(+14.29 \%)$ as well as the swelling anisotropy $(-9.05 \%)$ prove to be highly significant $(p=0.001)$.

\begin{tabular}{|c|c|c|c|c|c|c|}
\hline Material property & $\begin{array}{c}\text { Normal } \\
\text { beech }\end{array}$ & $\begin{array}{l}\text { Standard } \\
\text { deviation }\end{array}$ & $\begin{array}{l}\text { Red-hearted } \\
\text { beech }\end{array}$ & $\begin{array}{l}\text { Standard } \\
\text { deviation }\end{array}$ & $\begin{array}{l}\text { Average } \\
\text { diff. }(\%)\end{array}$ & $\begin{array}{c}P^{*}, \text { level of } \\
\text { significance } \%\end{array}$ \\
\hline Density $\left(\mathrm{kg} / \mathrm{m}^{3}\right)$ & 695 & \pm 42 & 714 & \pm 41 & +2.74 & $\leq 0.05$ \\
\hline Moisture content $(\%)$ & 9.2 & \pm 0.5 & 9.5 & \pm 0.4 & +3.26 & $\leq 0.01$ \\
\hline Annual growth rings (Number) & 10.1 & \pm 2.2 & 7.4 & \pm 1.2 & & $\leq 0.001$ \\
\hline Bending modulus $\left(\mathrm{N} / \mathrm{mm}^{2}\right)$ & 13006 & \pm 2109 & 13799 & \pm 1518 & +6.1 & $\leq 0.05$ \\
\hline Bending strength $\left(\mathrm{N} / \mathrm{mm}^{2}\right)$ & 127 & \pm 21 & 136 & \pm 17 & +7.09 & $\leq 0.05$ \\
\hline Tangential diff. swelling (\%) & 0.44 & \pm 0.04 & 0.45 & \pm 0.04 & +2.27 & $>0.05$ \\
\hline Radial diff. swelling (\%) & 0.21 & \pm 0.02 & 0.24 & \pm 0.03 & +14.29 & $\leq 0.001$ \\
\hline Swelling Anisotropy (\%) & 2.10 & \pm 0.19 & 1.91 & \pm 0.27 & -9.05 & $\leq 0.001$ \\
\hline Brinell-hardness tan. $\left(\mathrm{N} / \mathrm{mm}^{2}\right)$ & 26.87 & \pm 1.80 & 28.96 & \pm 2.52 & +7.78 & $\leq 0.001$ \\
\hline Brinell-hardness rad. $\left(\mathrm{N} / \mathrm{mm}^{2}\right)$ & 24.46 & \pm 2.17 & 25.59 & \pm 3.06 & +4.62 & $\leq 0.05$ \\
\hline
\end{tabular}

Table III. Physical, mechanical and technological properties of normal beech wood and beech wood with red heart $(n=50$, for Brinellhardness $n=240$ ).

* $t$-test after Student, two populations. 


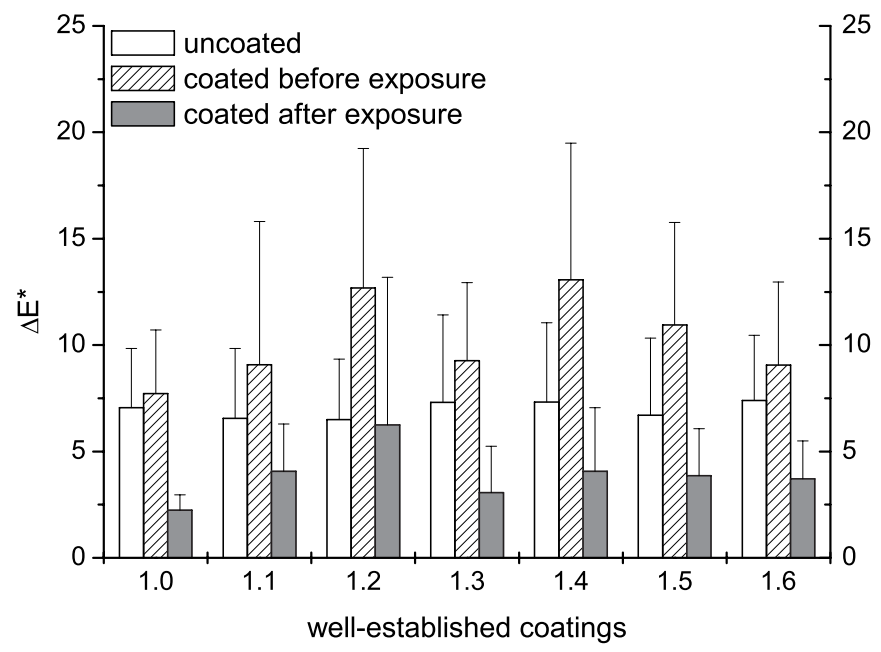

Figure 1. Colour difference of normal and red-hearted wood of the first sample series (well-established coatings) in the uncoated state and the coated state before and after $480 \mathrm{~h}$ of exposure.

The comparison of the Brinell-hardness of the normal and the red-hearted beech wood showed clear differences between the two groups. On the tangential section the red-hearted wood showed significantly higher values than normal wood $(+7.78 \%)$. On the radial section differences were smaller. The hardness in the samples with red heart tends to be higher $(+4.62 \%)$.

\subsection{Colour behaviour}

The investigation of the colour behaviour in this study pursued to determine the quantitative colour differences of normal and red-hearted wood and the behaviour of the colour difference during xenon-arc exposure as well as the examination of the influence of different coatings on the investigated colour changes of the material during xenon-arc exposure. For this purpose the samples were separated in 6 groups of well-established coatings (series 1) and 5 groups of newly developed coatings (series 2).

Figures 1 and 2 summarize the results of the comparison of normal and red-hearted wood. These figures show the colour difference $\Delta \mathrm{E}^{*}$ between the normal and red-hearted samples of each group in the original uncoated state, in the coated state before exposure and in the coated state after exposure. In both series the uncoated red-hearted material differed significantly from the uncoated normal material in chroma $C^{*}(p<0.05)$ as well as lightness $\mathrm{L}^{*}(p<0.001)$. This resulted in a clear difference in colour characteristics $\left(\Delta \mathrm{E}^{*}\right.$ value) between the redhearted and the normal material in each series in the uncoated state. This difference was relatively homogeneous across the different groups within each series.

The following surface coating clearly intensified the colour difference $\Delta \mathrm{E}^{*}$ between the red-hearted and the normal material. In both series certain treatments caused a stronger intensification of the colour difference than others. Overall the sample groups became less homogeneous in colour appearance in the coated state before xenon-arc exposure (Figs. 1 and 2).

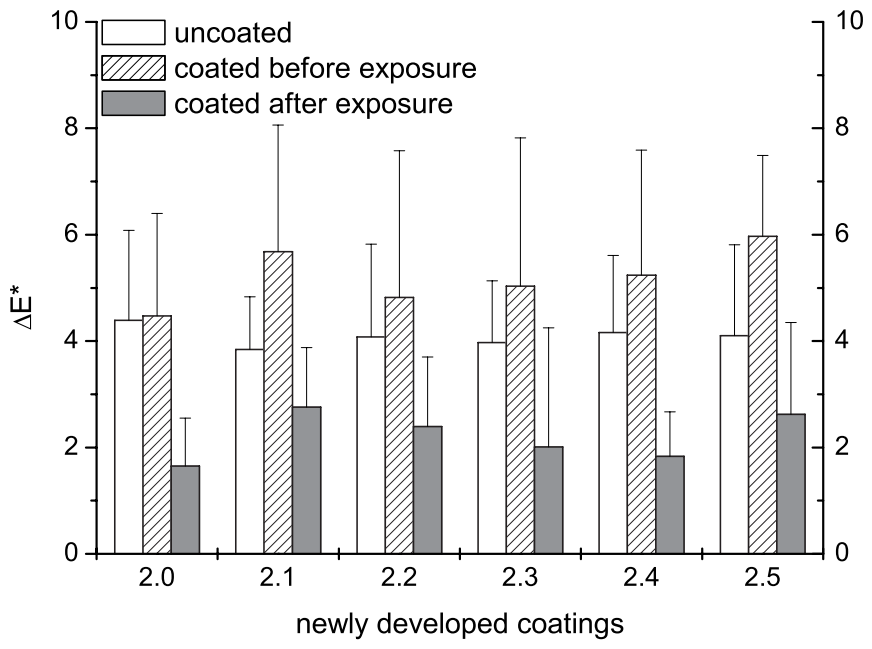

Figure 2. Colour difference of normal and red-hearted wood of the second sample series (newly developed coatings) in the uncoated state and the coated state before and after $480 \mathrm{~h}$ of exposure.

After $480 \mathrm{~h}$ of exposure the colour difference between normal and red-hearted wood is clearly reduced even below the values of the original material in the uncoated state. The original colour difference between normal wood and red-hearted wood decreases significantly under irradiation. The initial accentuation of the colour difference by the surface treatment gives way to a gradual diminishing of the differences during exposure (Figs. 1 and 2).

In the subjective visual assessment of the samples during exposure the most significant change in colour seemed to take place within the first $48 \mathrm{~h}$ of exposure. Four hundred and eighty hours of xenon-arc exposure obviously resulted in diminution of the differences in colour appearance of red-hearted and normal samples, and the colour of the two materials gradually became ever more similar. While normal beech darkened during exposure, the red-hearted wood exhibited lightening of its characteristic natural appearance, so after completion of exposure the optical differences between the two materials were hardly discernible.

Figures 3 and 4 summarize the development of colour change during xenon-arc exposure and thus the performance of the different coatings, applied on normal as well as on redhearted material, quantitatively in terms of the CIELAB numerical values. In Figures 3 and 4 the colour difference $\Delta E^{*}$ relates to the change in colour appearance of each coated sample during $480 \mathrm{~h}$ of xenon-arc exposure (group 1.0 and 2.0 are the untreated reference samples).

The differences in the nature and preparation of the substrates (veneer or solid wood) do not allow comparison of effectiveness of particular surface treatments to be made between the two general series. Relevant comparisons can be done only for treatments within a particular series. Figures 5 and 6 show that the application of the surface coatings clearly reduced the intensity and character of colour changes after xenon-arc exposure. $\Delta \mathrm{E}^{*}$ values of coated surfaces were $40 \%-60 \%$ lower than the values of the control samples (1.0 and 2.0). In the first series there is no single treatment or a sample that could be regarded 

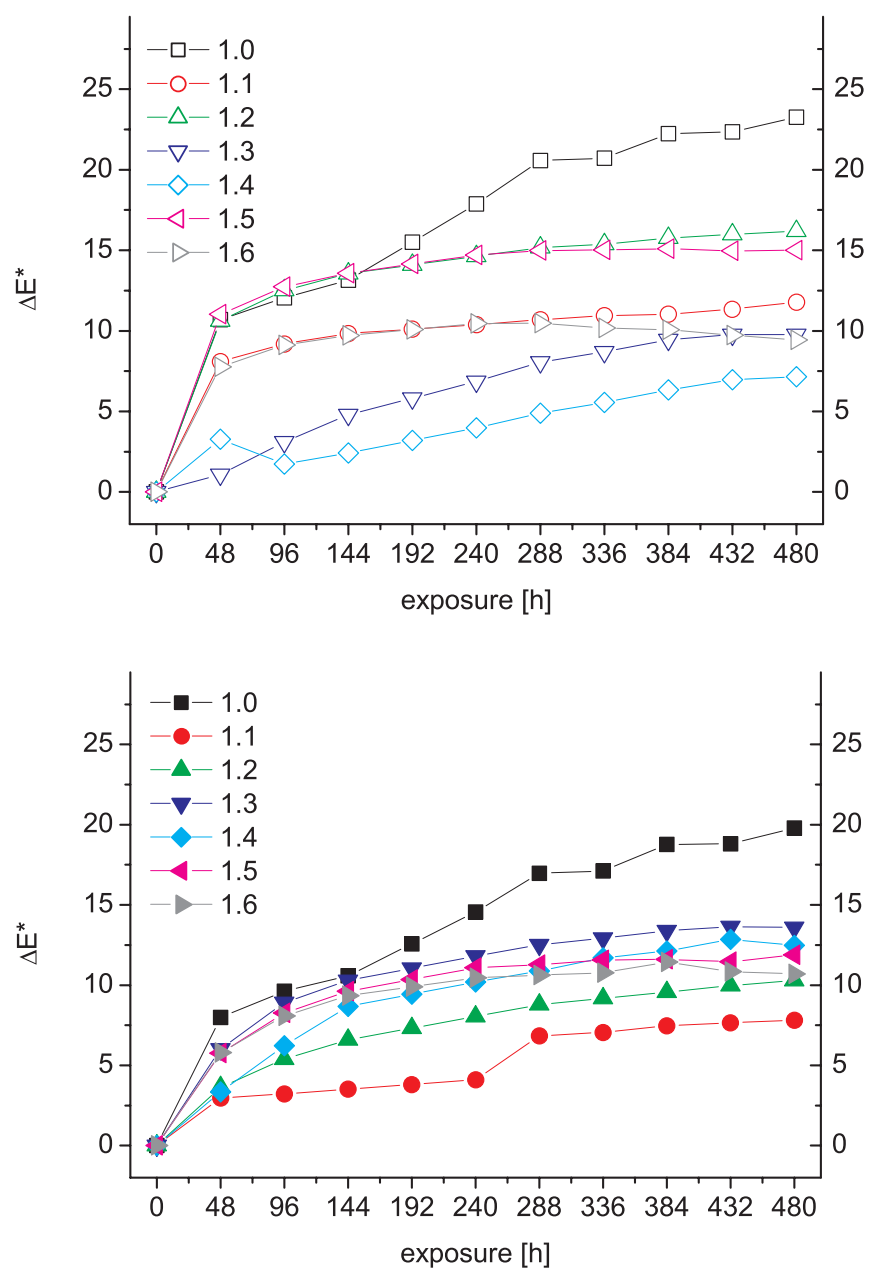

Figure 3. Development of colour characteristics $\Delta \mathrm{E}^{*}$ of the first sample group coated with well-established coatings during $480 \mathrm{~h}$ of exposure. Above: the behaviour of normal wood. Below: the behaviour of red-hearted wood.

stable. Moreover, the red-hearted material of the first series exhibited after irradiation a higher dissipation of colour differences $\Delta \mathrm{E}^{*}$ values than any material of normal wood (Fig. 5). A comparison of Figures 5 and 6 also indicates that stabilized finishes (second series) yielded more uniform colour of redhearted wood, and generally more homogeneous distribution of $\Delta \mathrm{E}^{*}$ values. In this series coating systems 2.3 and 2.5 can be regarded as slightly better than the other coatings in preventing colour changes during irradiation.

The visual as well as the quantitative assessment between the samples of normal and red-hearted wood confirms the observed diminishing of colour differences during exposure. A more detailed description of the quantitative as well as photographic results can be found in [32].

\subsection{Adhesion behaviour}

Table IV resumes the results of the adhesion tests.

Comparing of the strengths of the different adhesive systems the samples glued with 1 P PUR showed better strength after
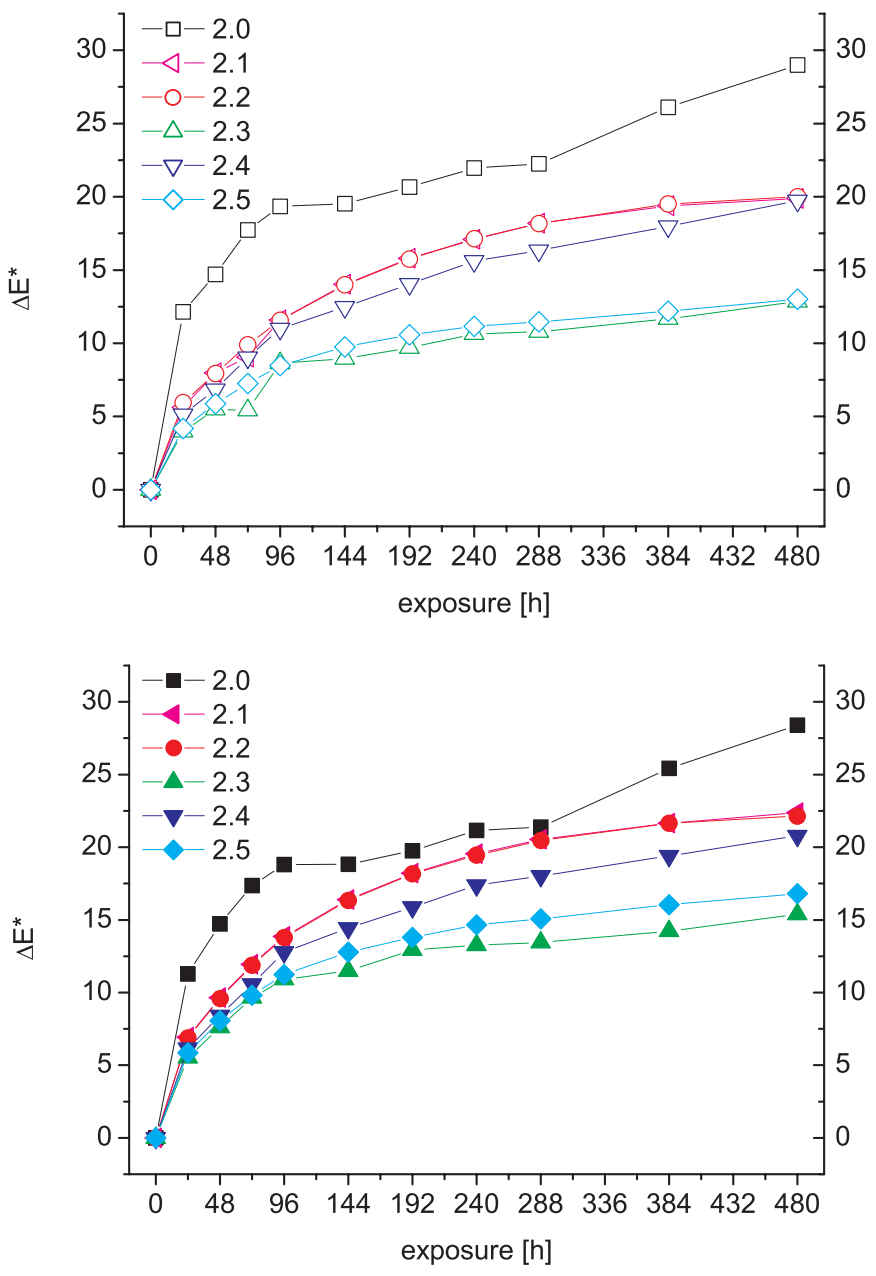

Figure 4. Development of colour characteristics $\Delta \mathrm{E}^{*}$ of the second sample group coated with newly developed coatings during $480 \mathrm{~h}$ of exposure. Above: the behaviour of normal wood. Below: the behaviour of red-hearted wood.

A1 treatment, whereas MUF bonded samples exhibited higher values in wet condition after the A4 treatment.

In comparison of the longitudinal shear strengths of glued normal and red-hearted beech wood after A1 treatment the redhearted beech glued with MUF showed significant higher strengths than normal beech. The values of the samples glued with 1 P PUR are comparable. After A4 treatment the redhearted samples glued with 1 P PUR showed significantly higher strengths than the samples of normal wood. The strengths of the red-hearted samples bonded with MUF are equal.

In all cases the high proportion of wood failure indicates that there is no difference in the bonding behaviour of the two assortments under normal moisture conditions. For the MUF bonded specimens the measured shear strength values correspond to the shear strength of solid wood.

Analysis of the fracture pattern of the samples after A1 treatment revealed a wood failure portion of $80 \%$ in the fracture surface of the red-hearted samples and a wood failure portion of $90 \%$ of the fracture surface of the normal samples glued with 


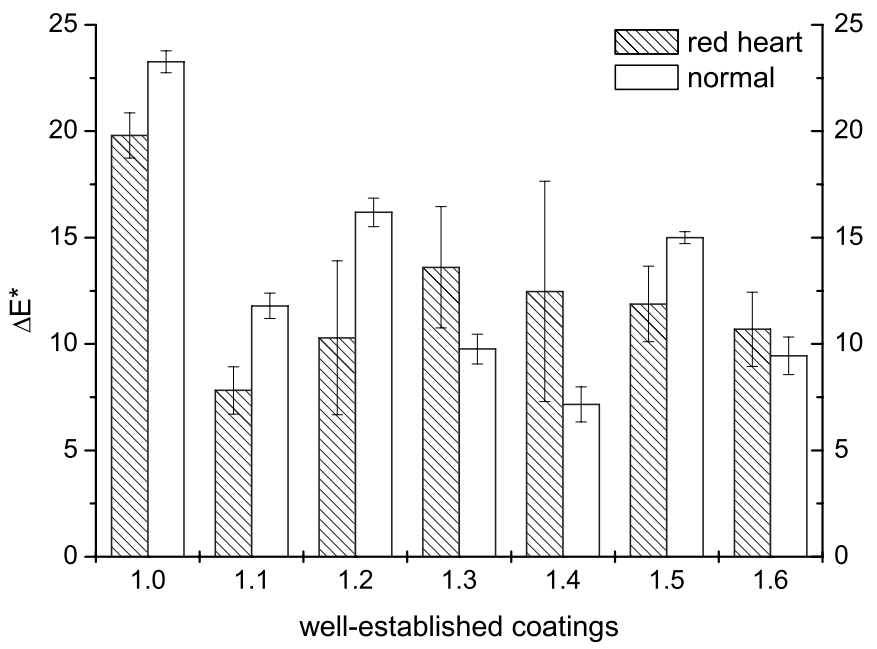

Figure 5. Colour change after $480 \mathrm{~h}$ of exposure of the first sample group coated with well-established coatings.

1 P PUR (Tab. IV). All samples glued with MUF showed a fibre portion of $100 \%$ after A1 treatment. Light-microscope analysis showed high penetration of the PUR into the wood structure, however also a considerable bubble accumulation within the glueline (Fig. 7). The bubbles derive from $\mathrm{CO}_{2}$ formation during curing of PUR. Light-microscope analysis of the samples of normal wood glued with MUF showed also high penetration, and in both assortments the adhesive is evenly distributed in the glueline.

After A4 treatment the fracture surface of the samples glued with MUF showed a still high fibre portion of $80 \%$ for normal beech and $60 \%$ for beech with red heart. Samples glued with 1 P PUR however showed no wood failure at all. These findings indicate that MUF as adhesive behaves better on beech wood under high moisture impact than the 1 P PUR adhesive used in this test. However, both adhesive systems do not exceed the limit values of $6 \mathrm{MPa}$ set in EN 301 [2] for structural adhesives. Based on the results achieved in these tests, no differences in the bonding behaviour of red-hearted and normal beech were found.

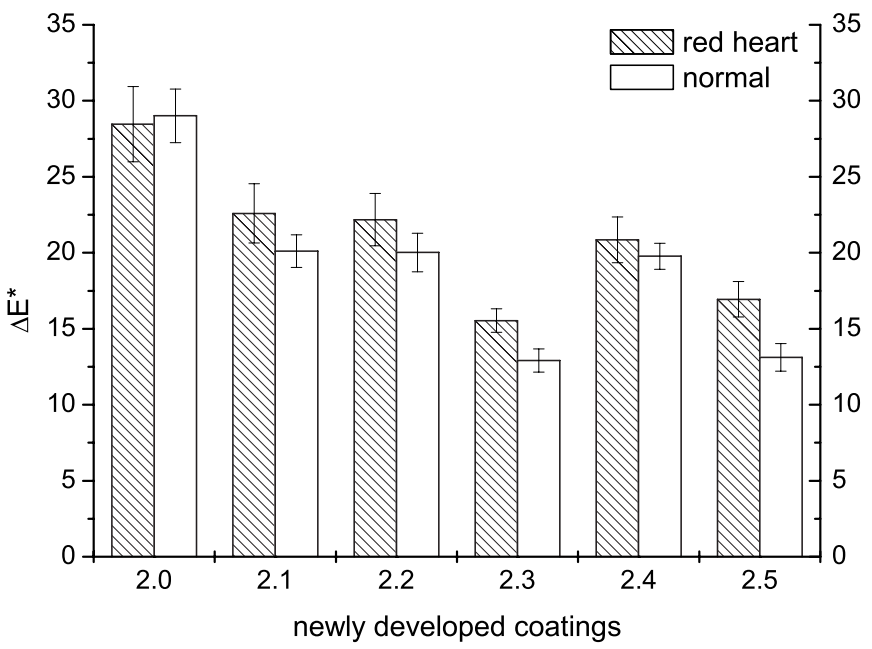

Figure 6. Colour change after $480 \mathrm{~h}$ of exposure of the second sample group coated with newly developed coatings.

\section{DISCUSSION}

\subsection{Physical, mechanical and technological properties}

The results of our study show that no difference in main mechanical and technological properties between beech with red heart and normal beech could be observed. Slight differences in physical and mechanical properties can be explained by the significant difference in the density of the material used in test (Tab. III) even coming from the same trunk. Since no direct and consistent relationship between ring width, density and related mechanical properties could be established in this work and other references $[24,25]$, we may conclude that the red-hearted beech could be well used for furniture production as normal wood provided that the colour is not regarded as its disadvantage.

The significantly higher values of the bending strength and the modulus of elasticity of the red-hearted sample group can be explained by the different densities of the sample-sets. The red-hearted samples were taken with the greatest possible distance to the pith, in order to limit the influence of juvenile wood, which has usually a somewhat greater lumina and less density.

Table IV. Longitudinal shear strength and wood failure of beech wood samples glued with 1 P PUR or Melamin-Urea-Formaldehyde (MUF) after A1- and A4- treatment according to EN 302-1 [1].

\begin{tabular}{|c|c|c|c|c|c|c|}
\hline & \multicolumn{3}{|c|}{ Normal beech wood } & \multicolumn{3}{|c|}{ Red-hearted beech wood } \\
\hline & $\begin{array}{l}\text { Long. shear strength } \\
\qquad\left(\mathrm{N} / \mathrm{mm}^{2}\right)\end{array}$ & $\begin{array}{l}\text { Standard deviation } \\
\qquad\left(\mathrm{N} / \mathrm{mm}^{2}\right)\end{array}$ & $\begin{array}{l}\text { Wood failure } \\
(\%)\end{array}$ & $\begin{array}{l}\text { Long. shear strength } \\
\left(\mathrm{N} / \mathrm{mm}^{2}\right)\end{array}$ & $\begin{array}{l}\text { Standard deviation } \\
\qquad\left(\mathrm{N} / \mathrm{mm}^{2}\right)\end{array}$ & $\begin{array}{l}\text { Wood failure } \\
\qquad \%)\end{array}$ \\
\hline A1 PUR & 12.80 & \pm 1.03 & 90 & 12.27 & \pm 1.09 & 80 \\
\hline A4 PUR & 3.35 & \pm 0.97 & 0 & 4.00 & \pm 0.93 & 0 \\
\hline A1 MUF & 10.60 & \pm 1.63 & 100 & 12.36 & \pm 1.50 & 100 \\
\hline A4 MUF & 5.42 & \pm 0.77 & 80 & 5.52 & \pm 0.95 & 60 \\
\hline
\end{tabular}



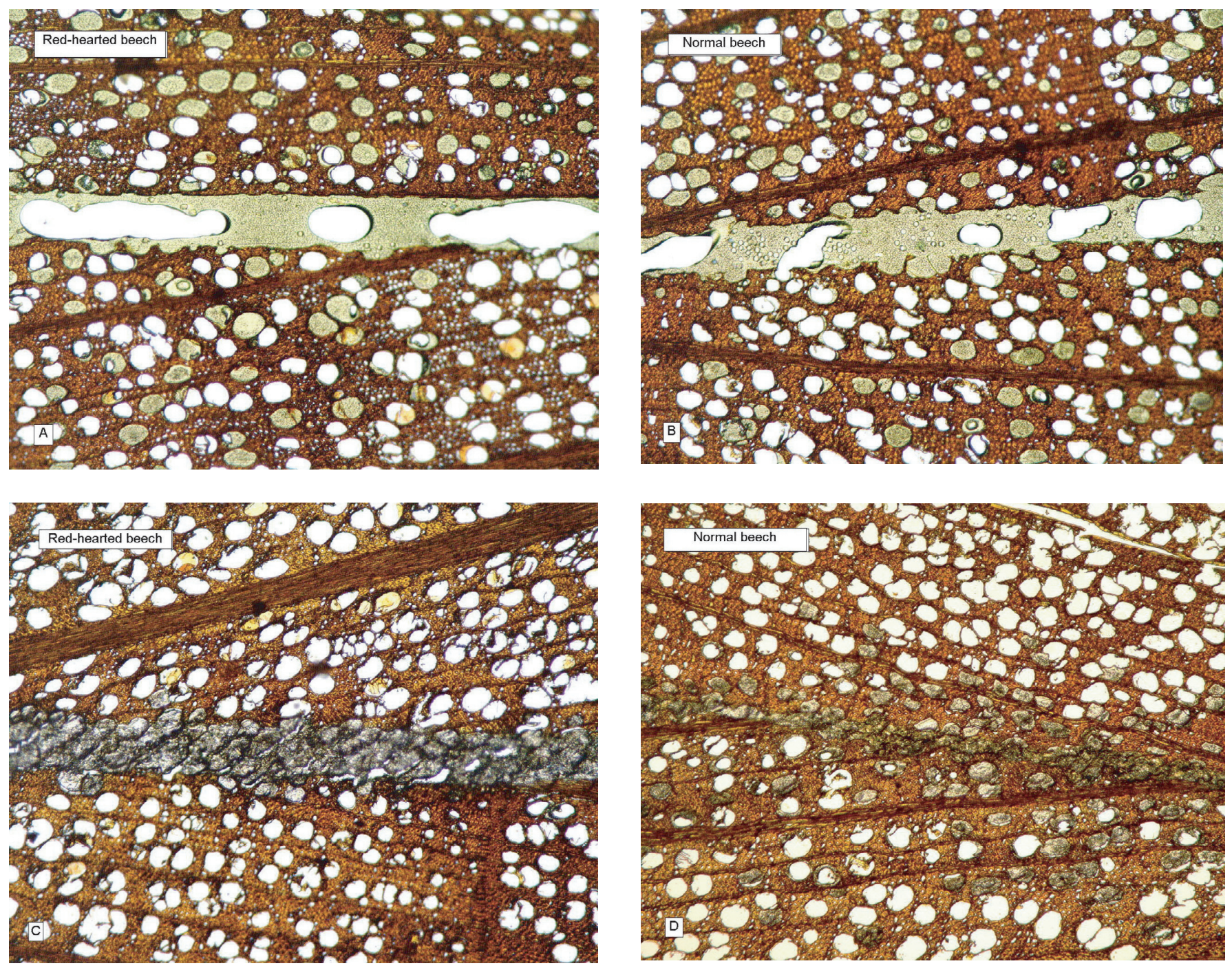

Figure 7. Above: Transverse section of beech wood, glued with 1 P PUR, A1 conditioning and testing (A and B) [1]; good penetration of the adhesive into the wood structure. Below: Transverse section of beech wood, glued with MUF, A1 conditioning and testing (C and D) [1]; good penetration of the adhesive into the wood structure of the normal beech (light micrograph).

Instead of the juvenile wood rather the higher density of the redhearted samples affected the results in our study. Molnàr et al. [30] however described in their investigations that the occurrence of juvenile wood within the pith of red-hearted beech trunks impaired the technological characteristics of the sample assortments due to internal stress. Investigations of Wobst [36] in terms of bending strength showed that the samples with red heart had a lower strength than the normal wood samples. The differences proved to be insubstantial. Similar results are shown by the investigations of Klebes et al. [24] who assessed that the bending strength and the modulus of elasticity of the two groups showed no systematic differences.

Apart from the density the swelling and shrinking behaviour of the wood is decisive for many uses. The more pronounced the humidity-dependent change in the anisotropy of the single shrinkage dimensions is the larger problems arise in the case of the processing.
The swelling behaviour in radial direction of the beech with red heart is significantly increased $(+14.29 \%)$, in tangential direction the two groups are comparable $(+2.27 \%)$. A significant difference was found for the lower swelling anisotropy $(-9.05 \%)$ of the red-hearted beech wood. Wobst [37] did not find a difference between the tangential and radial swelling behaviour of beech with red heart and normal beech wood. Also anisotropy values did not differ. Molnàr et al. [30] showed in his investigations that red heart shrinks least than normal wood (tangential: $-9.70 \%$; radial: $-3.15 \%$ ).

Little research was carried out so far regarding investigations of the Brinell-hardness of red-hearted wood. Molnàr et al. [30] compared the hardness of red-hearted and normal beech wood and showed that the hardness in radial and in tangential direction was up to $10 \%$ higher for the red-hearted wood. These differences could generally be confirmed in our investigations, however not in the same order of magnitude. Here the average 
differences in tangential direction amount to $+6.3 \%$ and in radial direction to $+4.4 \%$.

In general the investigation gave no evidence to deny the utilization of red-hearted beech in mass production for its physical and mechanical properties. Wobst [37] came to the same results. He stated in his study that the differences of technological properties between the logs are larger than the differences between red heart and sapwood of a single log so that the occurrence of red heart is of little importance for processing and utilization.

\subsection{Colour behaviour}

The first indication of photodegradation of wood is change in colour. Most lignocellulosic materials change toward a yellow or brown due to chemical breakdown of lignin and extractives. Some extractives have antioxidant properties which can limit the colour change of wood upon light [15]. The loss of methoxyl groups (delignification) during irradiation develops linearly with increasing yellowness. This links yellowing directly with photooxidation of lignin [29]. New surface coatings contain lignin stabilizing components in primer treatments to prevent delignification. No significant effect could be found for the coating systems containing such components (2-1, 2-2). Yellowing is observed at wood surfaces treated with more or less clear coatings, because light, especially ultraviolet light with wavelengths between 290 and $400 \mathrm{~nm}$, reaches and degrades the wood surface when passing through the coating [18]. In addition to inhibiting the discolouration of the coating it is also necessary to reduce the intensity of UV-light reaching the wood underneath the coating. Therefore new coatings often contain UV-absorbers and radical scavengers [21]. Their aim is on the one hand to transfer UV-irradiation into heat instead of photochemical processes of lignin degradation by UVscreeners and on the other hand to trap newly formed free radicals before they oxidise lignin which would cause the discolouration. Those newly formed coatings also showed the best results in our investigation (2-3, 2-5). However they could neither significantly prevent the general yellowing of the surfaces nor influence the general convergence in colour of the redhearted beech and normal beech. The investigated samples with and without red heart changed from an initially very different colour to a very similar yellowish appearance after xenon-arc irradiation despite the different surface treatments applied. The red heart chromophores are likely to be formed during oxidation and polymerization of phenolics [12]. These compounds are unstable to light and seem to determine the observed discolouration process of the red-hearted sample during exposure decisively. The reason for the convergence of the colour effect of red-hearted and normal beech probably is a combination of the described mechanisms of delignification in general and an increased break down of chromophores especially in the redhearted samples.

The investigation clearly showed that the difference in colour of normal beech and red-hearted beech diminishes after solar exposure. The original discolouration of the red heart as a reason for loss of quality and value of the wood is unjustified with respect to the long term utilization of the wood. However, surface coating and processing industries should develop tech- nologies that allow an accelerated colour change in the production phase of e.g. furniture.

\subsection{Adhesion behaviour}

The investigations carried out allow assessing the gluing properties of normal beech wood compared with red-hearted beech wood. The bonding quality is generally affected by numerous factors such as strength and elasticity of the adhesive, but also by the condition and properties of the wooden adherents. In our work the performance of two adhesive types was investigated.

All untreated (A1-conditioned) samples reached average shear strength values well above the minimum values required in EN 301 [2]. After being exposed to climate treatment A4, the strength values decreased as expected, but did not meet the requirements of EN 302 for any of the adhesives $\left(6 \mathrm{~N} / \mathrm{mm}^{2}\right)$. This indicates that the performance of both adhesive types under high moisture impact is insufficient. Both adhesives used have in common that they form transparent gluelines, so no phenolic or resorcin compounds has been used for their formulation. Both components are of brown colour and are known to contribute to the most high moisture stability of the traditional Phenol-Formaldehyde- (PF) or Resorcin-Formaldehyde- (RF) adhesives. Obviously the substitutes used in transparent formulations are not as effective, and the required limit values are difficult to achieve for this new generation of wood adhesives. However, it is interesting to note that the MUF strength values are insufficient although the wood failure exceeds the $50 \%$ level on both groups. The study confirms the weak interface performance of 1 P PUR under wettest conditions, reported in [33], although the penetration and physical interlocking of the resin into the wood is perfectly achieved (see Fig. 7). Our study underlines the fact that the test conditions in EN 302-1 [1] put the adhesives to their limits when high moisture stress is applied. On the other hand confirms the assessment of the long term performance of a 1 P PUR adhesive under practical conditions their safe applicability in load bearing timber structures.

At the beginning of the investigations we hypothesised whether accessory compounds of the red-hearted beech wood could affect the gluing. These compounds are synthesised through penetration of oxygen into the tissue inducing physiological and biochemical reactions [19]. These high-molecular compounds are not incorporated into the cell wall, but rather deposited in the cell lumina of the parenchyma cells. They are not very reactive hence do not contribute to decay resistance.

The results indicate that the quality of gluing is not dependent in the first instance on the wood condition (red-hearted wood/normal wood), but on the adhesive system and the grade of heating and wetting of the glued samples. Our findings support the research of Hapla and Fleischhut [20] who reported that the tensile strengths of the PVAC gluelines of red-hearted and normal steamed beech samples were closely similar.

Thus, the use of red-hearted beech wood for glued laminated structural members offers an opportunity for a value added application of this abundant hardwood resource. For an increased use in decorative furniture, the red-hearted beech should be steamed or moistured (briefly and only superficially), then exposed to UV-light in a tunnel in order to egalize and 
bleach the colour. Further research is necessary to determine the relevant parameters for such a technological upgrading.

Acknowledgements: The authors acknowledge financial support by the Fonds zur Förderung der Wald- und Holzforschung, Switzerland. We are indebted to 5 suppliers of paint systems and 2 suppliers of adhesive systems. We appreciate valuable comments on the manuscript by Dr. K. Richter and Prof. H. Turkulin. We wish to thank Dr. A. Einsele for helpful discussions and M. Rees, K. Weiss, W. Risi and A. Fischer for technical support.

\section{REFERENCES}

[1] EN 302-1 Adhesives for load-bearing timber structure; testing methods. Part 1: Determination of longitudinal tensile shear strength, 2001.

[2] EN 301 Adhesives, phenolic and aminoplastic for load-bearing timber structures - Classification and performance requirements, 2001.

[3] Artificial weathering and ageing of plastics and elastomers by exposure to filtered xenon arc radiation, 1989.

[4] EN 6174 Colorimetric Evaluation of Colour Differences of Surface Colours According to the CIELAB Formula, 1979.

[5] Colorimetry 1-8. Beuth Verlag GmbH, 1992.

[6] ISO 2808 Paints and varnishes - Determination of film thickness, Method No. 5: Measurement of dry-film thickness by microscope methods, 1997

[7] DIN 52186 Testing of wood; bending test, 1978.

[8] DIN 52182 Testing of wood; determination of density, 1976.

[9] DIN 52183 Testing of wood; determination of moisture content, 1977.

[10] DIN 52184 Testing of wood; determination of swelling and shrinkage, 1979.

[11] EN 1534 Wood and parquet flooring; determination of resistance, 2000.

[12] Albert L., Hofmann T., Nemeth Z.I., Retfalvi T., Koloszar J., Varga S., Csepregi I., Radial variation of total phenol content in beech (Fagus sylvatica L.) wood with and without red heartwood, Holz Roh. Werkst. 61 (2003) 227-230.

[13] Anonymus, Bundeswaldinventur II, Bundesministerium für Verbraucherschutz, Ernährung und Landwirtschaft (BMVEL), Bundesforschungsanstalt für Forst- und Holzwirtschaft, Institut für Forstökologie und Walderfassung, 2004.

[14] Anonymus, National Forest Inventory (NFI), Ministère de l'Agriculture, de l'Alimentation, de la Pêche et des Affaires rurales, 2004.

[15] Ayadi N., Lejeune F., Charrier F., Charrier B., Merlin A., Colour stability of heat-treated wood during artificial weathering, Holz Roh. Werkst. 61 (2003) 221-226.

[16] Bauch J., Discolouration in the wood of living and cut trees, IAWA 5 (1984) 92-98.

[17] Brändli U.B., Heller-Kellenberger I., Schweizerisches Landesforstinventar (2002) http://www.wsl.ch/land/products/lfi/resultate/ buche1.ehtml.

[18] Chang S.T., Chou P.L., Photo-discoloration of UV-curable acrylic coatings and the underlying wood, Polym. Degrad. Stabil. 63 (1999) 435-439.
[19] Dietrichs H.H., Chemisch-physiologische Untersuchungen über die Splint-Kern-Umwandlung der Rotbuche (Fagus sylvatica, L.) Ein Beitrag zur Frage der Holzverkernung, Mitteilungen der BFH 58 (1964) 141.

[20] Hapla F., Fleischhut T., Untersuchungen zur Verleimbarkeit von rotkernigem Buchen-Schnittholz, Abschlussbericht-Teil 2, Ministerium für Umwelt und Forsten des Landes Rheinland-Pfalz (Az.: FVA-1236/2V-2001), 2003, p. 31.

[21] Hayoz P., Peter W., Rogez D., A new innovative stabilization method for the protection of natural wood, Prog. Org. Coat. 48 (2003) 297-309.

[22] Huss J., Manning D.B., Natural Regeneration of Beech Forests in Europe - Germany: Approaches, Problems, Recent Advances and Recommendations, Nat-man Project, 2003, p. 19.

[23] Janin G., Mesure de la couleur du bois : intérêt forestier et industriel, Ann. Sci. For. 44 (1987) 455-472.

[24] Klebes J., Mahler G., Höwecke B., Holzkundliche Untersuchungen an Buchen mit neuartigen Waldschäden, Forstliche Versuchs- und Forschungsanstalt, 1988, p. 65.

[25] Klotzenburg C., Die Abhängigkeit der Holzeigenschaften der Rotbuche (Fagus sylvatica L.) von soziologischer Stellung und anderen Wuchsbedingungen, Forstl. Fak. Univ. Göttingen, Dissertation (1966) p. 121.

[26] Koch G., Bauch J., Puls J., Schwab E., Welling J., Holzverfärbungen der Rotbuche (Fagus sylvatica L.) und Möglichkeiten vorbeugender Massnahmen, Holz-Zentralblatt 126 (6) (2000) 74-75.

[27] Koch G., Bauch J., Puls J., Schwab E., Welling J., Rotkern der Buche, Holz-Zentralblatt 107 (2002) 1272-1273.

[28] Koch G., Bauch J., Puls J., Welling J., Ursachen und wirtschaftliche Bedeutung von Holzverfärbungen, AFZ/Der Wald 6 (2002) 315318.

[29] Leary G.L., The yellowing of wood by light. Part I., TAPPI J. 50 (1967) 17-19.

[30] Molnàr S., Nemeth R., Feher S., Tolvaj L., Papp G., Varga F., Apostol T., Technical and technological properties of Hungarian beech wood consider the red heart, Drevarsky Vyskum 46 (2001) 21-29.

[31] Muhs H.J., Wuehlisch G.v., The scientific basis for the evaluation of forest genetic resources of beech. Proc. of a EC-workshop, Ahrensburg, Working document for the EC, DG, VI, Brussels, 1993.

[32] Pöhler E., Klingner R., Künniger T., Rotkerniges Buchenholz Vorkommen, Eigenschaften und Verwendungsmöglichkeiten, EMPA - Eidgenössische Materialprüfungs- und Forschungsanstalt, 2004, p. 85.

[33] Richter K., Schirle M.A., Behaviour of 1 K PUR adhesives under increased moisture and temperature conditions, Lignovisionen 4 (2002) 149-154.

[34] Shengquan L., Loup C., Gril J., Dumonceaud O., Thibaut A., Thibaut B., Studies on European beech (Fagus sylvatica L.). Part 1: Variations of wood colour parameters, Ann. Sci. For. 62 (2005) 625-632.

[35] Stübi T., Niemz P., Neues Messgerät zur Bestimmung der Härte, Holz-Zentralblatt 114 (2000) 1524, 1526.

[36] Wobst H., Auswirkungen der Rotkernigkeit auf kennzeichnende Eigenschaften und industrielle Verwendung von Buchenstammholz. Forstliche Fakultät Dissertation, 1969, p. 173.

[37] Wobst H., Über die Auswirkungen der Rotkernigkeit des Buchenholzes auf seine Verwendung, Forst- Holzwirt. 4 (1972) 80-83. 